\title{
Ten minutes with Dr lan Reckless, Medical Director, Milton Keynes University Hospital NHS Foundation Trust
}

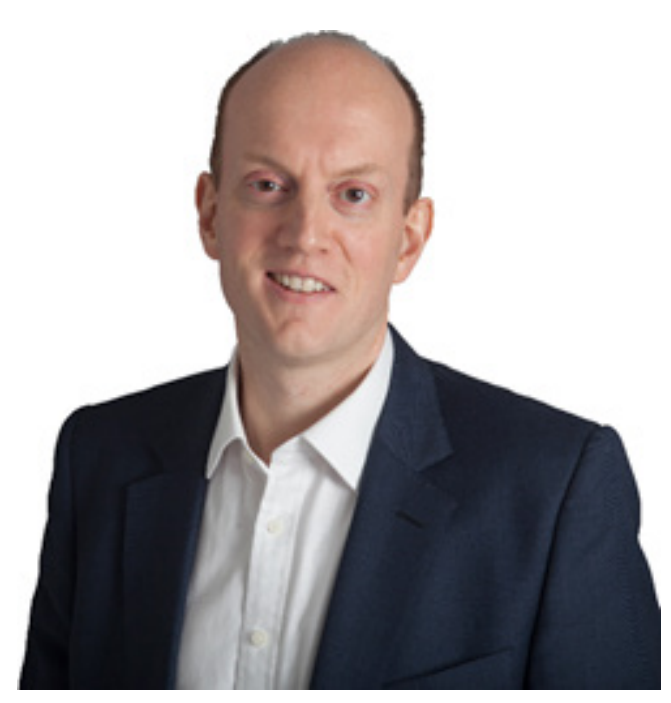

FIRST AND FOREMOST, ARE THERE ANY KEY LEADERSHIP MESSAGES YOU WANT TO GET OUT TO OUR READERSHIP?

For me, there are three key messages based on my personal battle against COVID-19 so far:

1. Pace. The adage 'this is a marathon not a sprint' is becoming worn. However, it is key to establishing effective communication within an organisation, and to maintaining collaborative working between colleagues.

2. Breadth. It is vital to remain mindful of the concerns and anxieties of all groups of staff (expressed or unsaid)—rather than to lose hearts and minds by focusing too quickly and closely on specific and narrow issues (for example, the provision of critical care).

3. Team. To the extent that infectious diseases affect everyone, and are said to be a great levellers, COVID-19 is no different. The Professor of Surgery may find herself working in the role of house physician. The domestic, cleaning the Emergency Department, is every bit as important as the Executive. Acknowledge and celebrate this.

\section{TELL US A LITTLE BIT ABOUT YOUR LEADERSHIP ROLE AND HOW IT IS CHANGING AS A RESULT OF THE \\ PANDEMIC?}

I am Medical Director of a single site acute hospital. The day job is broad, and within our executive team we are generally comfortable working across each other's portfolios. My clinical background is as an acute and stroke physician. The pandemic has led us to focus on personal visibility in the organisation (in my case, with the medical workforce), leadership in our own professional sphere (in my case, an emphasis on revised clinical pathways, professionalism and ethics) and ensuring close working with colleagues in the wider health economy-the emphasis of external relationships has rapidly shifted from politics to operational delivery.
Biography

Ian Reckless is Medical Director at Milton Keynes University Hospital NHS Foundation Trust, and Consultant in Stroke and General Medicine in Milton Keynes and at Oxford University Hospitals NHS Foundation Trust. He continues to work clinically.

He qualified from St George's Hospital Medical School, London and undertook specialist training in the Oxford region.

He worked as Special Adviser to the Healthcare Commission in 2004, and as Special Assistant to the Chief Medical Officer in 2005-06. He was appointed Consultant Physician and Senior NIHR Research Fellow at Oxford University Hospitals in 2007. Having been Associate Medical Director (Quality), and Clinical Director, Neurosciences, in Oxford, he became Medical Director at Milton Keynes in April 2016.

He has a particular interest in postgraduate education, was previously a Training Programme Director, and has authored books on general medicine, and the interface between medicine and the law.

\section{WHAT EVENTS IN YOUR PAST EXPERIENCE ARE MOST INFORMING YOUR LEADERSHIP IN THIS PANDEMIC?}

In Milton Keynes, we were early off the starting blocks with respect to COVID-19. We hosted one of the two repatriation and quarantine centres for residents of Wuhan Province returning to the UK in February. This got us thinking about infection prevention and control, and novel clinical pathways some weeks ahead of our peers. In addition, we cared for the second COVID-19 fatality in the UK-a man returning from an overseas cruise. Both experiences led us to focus early on COVID-19-the science, the anxiety and the media - and that has been very helpful.

Other experiences which have been informative for me include working as an expedition medic in Outer Mongolia 20 years ago- the team arrived in the midst of a foot and mouth outbreak (indeed we were accused of importing it!), and during the expedition I found myself making rationing decisions, and committing colleagues to large amounts of precautionary expenditure-in something of a 'black market'. I also spent a year working with the then Chief Medical Officer at the Department of Health, and developed a sense of the symbiotic, but sometimes strained, relationship between government, profession and service.

\section{WHAT ARE YOU FINDING THE BIGGEST CHALLENGES?}

There are some reflex responses to this question-delivering at a local level on the political rhetoric set out in national daily news conferences, with confidence and supply of personal protective equipment among them. However, there are more fundamental issues at play. The immediate response to many challenges in acute healthcare is to bring teams of people together, to brief on the key issues, to understand perspectives, to reassure and then to instil a sense of focus and urgency for a short sharp period of intense activity. The COVID-19 pandemic is different in many ways.

First, the challenge will, assuming 'the curve is flattened', continue relentlessly for many months. 
Second, bringing staff together for collaborative work, conversation and mutual support is increasingly difficult as we are rightly concerned about the safety of ourselves and each other.

Finally, staff are having to knuckle down to a period of intense working, and they are being forced to question fundamentals; working well outside their comfort zones and with staff ratios that would shock in normal times.

\section{ANY PARTICULAR SURPRISES?}

We are familiar with the concept of disruptive innovation in healthcare ${ }^{1}$ but COVID-19 is leading to fundamental service transformation and technology adoption which will surely survive long beyond the pandemic: non face-to-face contacts; videoconferencing; remote working; a renewed staff offer in terms of workplace facilities and well-being; consultant delivered services; and, perhaps most importantly, the rebirth of 'team' in medicine.

\section{ARE YOU SEEING ANY BEHAVIOURS FROM COLLEAGUES THAT ENCOURAGE OR INSPIRE YOU?}

I have observed, for some years, that dynamic and energetic new consultants often appear to struggle to make their mark, following appointment. This may in part be a protective process of acclimatisation to a new team and environment. Over the course of the pandemic to date, I have been struck by the strong leadership shown by two cohorts of consultants-the new consultants, who have lost their hesitancy and reserve, coming to the fore to push and enact their ideas; and the most senior consultants, who have quickly reminded us all of the centrality of professional duty and generalism.

\section{HOW ARE YOU MAINTAINING KINDNESS AND COMPASSION?}

We keep on talking-whether face-to-face or via videoconferencing. We listen and we respond-even if to say 'no' to an idea or suggestion. Vacuums and obfuscation can be hallmarks of healthcare management-we are trying to avoid both. We are focusing on being one team-the domestic is as key to the effort as the consultant, we need to look after those in self-isolation, and empathise with those colleagues who find themselves unable to contribute on the front line. In the medical sphere, we focus on our profession-we are doctors first, specialists second. The same is true for colleagues in other disciplines; the research nurse or governance specialist back on the general ward.

\section{ARE THERE ANY IDEAS OR READINGS THAT YOU FIND HELPFUL FOR INSPIRATION AND SUPPORT THAT YOU WOULD RECOMMEND TO OTHERS?}

I heard David Nott talk at a graduation last year and was moved to read his book War doctor: Surgery on the front line ${ }^{2}$ that same evening. I was struck by Nott's stamina and drive. I also reflected that context is central to our working lives, indeed we sometimes let context define us. To be effective outside our comfort zonewhen the context is turned on its head-our values and professionalism are the key foundations.

\section{WHAT ARE YOU LOOKING FOR FROM YOUR LEADERS?}

I am looking for leaders to focus on versatility and pragmatism. Some of us are more suited than others to dealing with grey and ambiguity. Right now there is an abundance of greyness and ambiguity. I am also looking to leaders - and I mean that term in a very inclusive and informal sense - to appreciate the power of their positions. The actions of leaders - rather than their words - have a large audience and the impact of actions (positive or negative) ripples widely.

\section{Ian Reckless, ${ }^{1}$ Anthony Berendt ${ }^{2}$}

${ }^{1}$ Milton Keynes University Hospital, Milton Keynes, UK

${ }^{2}$ Oxford, UK

Correspondence to Dr Anthony Berendt, Oxford, UK; a.berendt@ntlworld.com

Twitter Anthony Berendt @tony_berendt

Funding The authors have not declared a specific grant for this research from any funding agency in the public, commercial or not-for-profit sectors.

Competing interests None declared.

Patient consent for publication Not required.

Provenance and peer review Not commissioned; internally peer reviewed.

Data availability statement All data relevant to the study is included in the article.

This article is made freely available for use in accordance with BMJ's website terms and conditions for the duration of the covid-19 pandemic or until otherwise determined by BMJ. You may use, download and print the article for any lawful, non-commercial purpose (including text and data mining) provided that all copyright notices and trade marks are retained.

(c) Author(s) (or their employer(s)) 2020. No commercial re-use. See rights and permissions. Published by BMJ.

\section{Check for updates}

To cite: Reckless I, Berendt A. BMJ Leader 2020;4:90-91.

Received 7 April 2020

Accepted 8 April 2020

Published Online First 17 April 2020

BMJ Leader 2020;4:90-91.

doi:10.1136/leader-2020-000256

\section{REFERENCES}

1 Clayton M, Christensen CM, Bohmer RMJ, et al. "Will Disruptive Innovations Cure Health Care?" Harvard Business Review (Sept-Oct) 1-10, 2000. Available: https://hbr. org/2000/09/will-disruptive-innovations-cure-health-care

2 Nott D. "War Doctor" (Picador, London ISBN 978-1-5098-3704-5), 2019. 